\section{Toronto Declaration on Equity in Health ${ }^{1}$}

Key words: health status, health inequalities, equity, socioeconomic factors, international cooperation.

\footnotetext{
Based on: International Society for Equity in Health. Toronto Declaration on Equity in Health [unpublished document]. Toronto, Ontario, Canada: ISEqH; 2002.
}

The idea of organizing an international scientific society focused on equity in health began to build momentum in the mid-1990s, when both the political sector and the scientific sector were showing an increasing interest in and attention to health inequities. In early 1996 the first draft of a constitution for such a society was developed and then circulated to some 150 interested individuals. In March of that year the International Society for Equity in Health (ISEqH) was formally incorporated in the state of Maryland, in the United States of America.

Among the specific purposes of the ISEqH are to promote equity and to expose inequity in health and in health care services internationally, to support the dissemination of conceptual and methodological knowledge on issues related to equity in health and health care services, and to advance research related to equity in health.

Since being established, the ISEqH has held two major international conferences. The first one was in Havana, Cuba, in June 2000. More than 200 persons from over 30 countries attended, and 62 scientific papers and 32 posters were presented. The second ISEqH international conference, which was held in Toronto, Canada, in June 2002, focused on research in the service of policy and advocacy for health and health services. Besides presentations of scientific papers, poster sessions, and workshops, a key event at the Toronto meeting was the approval of a resolution calling for the ISEqH to issue a declaration laying out its position on global health equity.

A drafting committee was nominated to prepare a declaration for review by the ISEqH Board of Directors. The committee forwarded its draft to the ISEqH Board in August 2002. The Board reviewed the document, and, with some revisions, approved it and released it publicly in October 2002. The text of the ISEqH declaration appears below.

\section{THE TORONTO DECLARATION ON EQUITY IN HEALTH}

\section{Equity in health is a cornerstone of individual, community, societal and international well-being.}

The Conference heard papers presented on a wide range of issues relevant to the understanding and promotion of health equity, from clinical and 
medical interventions and programs through to health system research outcomes.

\section{ISEqH notes that:}

- Equity in health is built upon people having access to the resources, capacities and power they need to act upon the circumstances of their lives that determine their health. Hence, governments and international agencies must develop policies and programs built not only on equitable access and outcomes to primary care but also on the social, economic and environmental determinants of health.

- Equity in health outcomes must be a central health goal of health care professionals, citizens and their governments. Economic efficiency in health systems should serve this goal and never be placed above it.

- Inequities in access and outcomes are not restricted to any one health care or economic system. Inequities in health are experienced in most countries regardless of their level of development. In virtually every country, people living in poverty and indigenous people have worse health outcomes. Discriminatory practices and social exclusion in different countries create health inequities for many other groups, including women, racialized and ethnic minorities, sexual minorities, immigrants and refugees, older people and people with disabilities and of minority faith.

- The expansion of the private sector in the course of globalization of trade and finance has been associated with growing inequalities in health outcomes between and within countries. The potential of globalization to advance health outcomes for all through the equitable distribution of new technologies in treatments, communications and information sharing must be realised. The potential of globalization to increase wealth should be accompanied by stronger international and national regulatory structures for effective wealth re-distribution and ecosystem sustainability.

- Human rights are central to equity in health. Strengthening participatory political and economic systems - and their transparency and accountability-will help guarantee fundamental human rights. Such rights are social, and not just civil, political and economic.

- The use of locally centred and culturally appropriate evidence on the equity outcomes of policy making in health systems, health-determining sectors and in clinical decision making is central to improvements in overall health outcomes. Tools to assist governments, citizens and civil society organizations in assessing equity outcomes exist and need to be used.

- Improvements in health outcomes that are both equitable and sustainable require well-developed and maintained public infrastructures. Investment in and support of the health workforce in particular must be a key strategy for health equity.

\section{ISEqH believes that:}

- Challenges to the underlying political, economic and social reasons for growing health inequalities and inequities are needed urgently. All health professionals must affirm their commitments to engage in such challenges. Programs to improve population health must promote an effective health dimension to social, economic and environmental policy.

- International organizations must consistently pursue ethical policies and strategies in all aspects of their work. This is especially so in the area of trade and development. Public and individual health should not be secondary outcomes to economic and trade growth or the protection of trade patents and intellectual property.

- Increased resources and investment in public health systems and health-promoting economic and environmental conditions are urgently required in developing and least developed countries. Improvements in health outcomes that are both equitable and sustainable require well-developed and maintained public infrastructures.

- Indicators of health inequalities and inequities must be included in national, regional and local monitoring and evaluation systems; such systems should be locally centred and culturally appropriate. People need to better understand the meanings and outcomes of all public and private corporate decision-making on their health.

- Investing in primary health care and public health must be the priority in health system reform in developed countries, and health system development in poorer nations. The global momentum towards increased privatisation of public health care, and investment on technologically expensive interventions that reach only a minority of the world's citizens, must be reversed.

- Knowledge systems, including health and science studies, are locally produced and culturally situated. Knowledge systems and structures from developed countries have dominated the world, first through colonialism and now through corporate globalization. This domination appropriates local knowledge systems, often leading to their demise. Supports to enhance these knowledge systems, especially regarding health and indigenous forms of social structures, are important in promoting equity in health.

- Equitable community partnerships embodying the principles and practices of community development are important for equity in health at the local level. Such practices ensure that both processes and outcomes 
are culturally appropriate, racially and ethnically sensitive, linguistically accessible as well as class, faith, gender, age and sexual identity relevant.

- The health of the environment, both local and global, is central to the health of the population. Development projects and policies must be planned so they do not create or exacerbate environmental degradation, or increase environmentally mediated health problems.

\section{ISEqH calls on:}

- The World Health Organization to re-emphasise and promote to member countries the importance of primary health care and primary prevention in healthdetermining sectors. Primary health care must reemerge as the focus for equitable and sustainable health outcomes and improvements. At the same time, health policies must be linked with employment, income maintenance, social welfare, housing and education. Investment in health and in an equitable society is an investment that pays off, for health affects the whole society.

- The World Health Organization to become more active in international governance and trade negotiations. In particular, the $\mathrm{WHO}$, and its member countries, must ensure that the right to health takes precedence over trade obligations.

- Governments in all countries to become more transparent in their trade relations. Economic criteria associated with increased trade liberalization must be held accountable for how [they] improve equity in health and human development, and sustainability of the environment.

- Governments in all countries to adopt transparent and participatory systems of government, governance and economy. The health of people must become one of the key goals by which governance decisions are made.

- Health professionals and their organizations to commit themselves to challenge public and private policy decisions that increase inequities in health, and to applaud those decisions that increase equity in health. We must all become champions for a new world order that is healthier, fairer and sustainable.

More information on the various activities of the ISEqH and on membership in the group is avail- able from the group's Web site, at: http://www. iseqh.org. Interested persons can also contact the ISEqH at: International Society for Equity in Health, Department of Family and Community Medicine, 256 McCaul Street, Second Floor, Toronto, Ontario, M5T 1W5 Canada; telephone: (416) 978-3763; fax: (416) 978-3912; e-mail: iseqh.exec@utoronto.ca

\section{SINOPSIS}

\section{La Declaración de Toronto sobre la Equidad en Salud}

La noción de organizar una sociedad científica orientada hacia lograr la equidad en materia de salud empezó a cobrar auge a mediados de los años noventa, y en marzo de 1996 la Sociedad Internacional para la Equidad en Salud (International Society for Equity in Health, ISEqH) fue establecida formalmente. Desde entonces, el grupo ha celebrado dos conferencias internacionales importantes, la primera en La Habana, Cuba, en junio de 2000, y la segunda en Toronto, Canadá, en junio de 2002. Un evento clave en la reunión de Toronto fue la aprobación de una resolución solicitando a la ISEqH que emitiera una declaración donde se describiera su postura en torno a la equidad en materia de salud en el mundo entero. Después de revisar una versión preliminar de la declaración, la Junta Directiva de la ISEqH redactó el documento final y lo dio a conocer públicamente en octubre de 2002. La declaración expresa varias creencias básicas y hace un llamado a los gobiernos, a los profesionales de la salud y a las organizaciones internacionales para que den una serie de pasos, entre ellos los siguientes: que la Organización Mundial de la Salud (OMS) reafirme y promueva entre sus Estados Miembros la importancia de la atención primaria de salud y de la prevención primaria en los sectores que inciden sobre la salud; que la OMS adopte un papel más activo en las negociaciones relacionadas con la gobernancia y el comercio internacionales; que los gobiernos de todos los países procedan con mayor transparencia en sus relaciones comerciales; que dichos gobiernos adopten sistemas de gobierno, gobernancia y economía más transparentes y participativos; y que los profesionales de la salud y sus respectivas organizaciones se comprometan a rebatir toda decisión de los sectores público y privado que incremente las inequidades en materia de salud y a aclamar toda decisión encaminada a mejorar la equidad. 